\title{
Conception and Execution of an Energy Innovation Program:Top-Down and Bottom-Up Analyses of the Brazilian National Program for Production and Use of Biodiesel
}

\author{
Adalberto Mantovani Martiniano de Azevedo', Newton Müller Pereira²
}

\begin{abstract}
The National Program for Production and Use of Biodiesel aims to partially replace petroleum diesel consumed in Brazil by biodiesel. PNPB costs are subsidized by government and diesel consumers, based on economical, environmental and social benefits. Rules and incentives have been created in order to create a sectoral innovation system congruent with PNPB's objectives. Nevertheless, PNPB didn't reach its goals, especially social policy goals. The paper analyzes PNPB by applying public policy analysis methodologies. Top-down and bottom-up approaches have been adopted. Top-down approach investigates PNPB's conception, focusing Program's rules and results expected by formulators. Bottom-up approach investigates PNPB's execution, focusing public/private actors enrolled on PNPB. Shortcomings identified are mainly related to the coordination of public/private actors and the Program's goals.
\end{abstract}

Keywords: public policies evaluation; biodiesel; sectoral systems of innovation; social policies.

\footnotetext{
'Center for Engineering, Modeling and Applied Social Sciences, Federal University of ABC (UFABC).Alameda Gaspar Nogueira, I62,AP 84B, Bairro Jardim, Santo André-SP, Brasil. 09090-0 I0. Phone: 55 (19) 9860-884I. E-mail: adalberto.azevedo@ufabc.edu.br 2Department of Science and Technology Policy, State University of Campinas (Unicamp). Cidade Universitária Zeferino Vaz - Distrito de Barão de Geraldo Caixa Postal 6152, Campinas-SP, Brasil. I3083-970. Phone: 55 (19) 352I 4555. E-mail: newpe@ige.unicamp.br
} 


\section{Introduction}

"[...] I always say for those people who talk to me: in my opinion, the biggest project in Brazil at the moment is the biodiesel project. It has been conceived to steer the Northeast region development, above all the poorest regions, through castor oil crops. Of course, biodiesel can be made from soybeans or palm oil in the North Region. However, in the poorest regions of Brazil, we want to boost the castor oil plantations in order to generate thousands and thousands of jobs. As I always say: a job gives the human being its dignity" (Quoted from President Luiz Inácio Lula da Silva speech in 2005).

The speech quote reproduced above reveals much of the expectations generated by the National Program for Production and Use of Biodiesel (PNPB), a public policy implemented in the first mandate of President Lula (2003-2007) with the primary objective to generate income for farmers and rural workers that live in the poorest regions of Brazil. These farmers would boost their income by providing raw materials to biodiesel production. By making mandatory the blend of $2 \%$ of biodiesel in all petroleum diesel consumed in Brazil, it was expected to generate economical benefits by diversifying energy sources, and environmental benefits by reducing the emissions of pollutant gases.

The launching of PNPB has been followed by an intense advertising campaign: the Brazilian energy corporation Petrobras in an advertising forecasted that economically excluded farmers could "raise energy". The President Lula da Silva, in national and international meetings, distributed biodiesel samples and castor oil seeds. Between 2004 and 20 I0, twenty four presidential speeches dealt with the PNPB, twelve of them in biodiesel plants inaugurations, according to information available at the press agency of the Federal Government web's page (Secretaria de Imprensa da Presidência da República, n.d.).

In order to fulfill PNPB purposes, the Program managers have created a regulatory framework that establishes rules and incentives, including the mandatory use of biodiesel blends, tax exemptions to producers, financial funding to research institutions and facilitated credit to support biodiesel plants investments, as well as for the acquisition of equipment fueled by biodiesel.

Six years after the Program launching, PNPB did not achieve the main objectives established in the Program. The great increase biodiesel industrial production was only possible by the participation of big commodities producers, mostly soybeans producers. Most of the investments in biodiesel plants are concentrated in commodities production regions, not in the poorest regions excluded by the commercial agrobusiness market. The big biodiesel plants use imported technology. Environmental and economic benefits are highly questionable. Finally, biodiesel production costs do not allow its price to be competitive with petroleum diesel prices, and biodiesel still requires subsidies to enter the fuels market. Taking into consideration these problems, it is quite difficult to justify the subsidies paid by consumers and the government to make feasible biodiesel insertion on the Brazilian fuels market.

The present paper aims to explain the causes of PNPB shortcomings, applying public policy analysis methodologies (Hogwood and Gunn, 1984) to describe and analyze conception, implementation, and execution of PNPB. To do so, the objectives proposed on the Program's conception have been compared with the Program's execution and results, as proposed by Pressman and Wildavsky (1984). This has been made by a top-down perspective analysis, focusing on the central actors enrolled with the conception and implementation of PNPB, and by a bottom-up perspective analysis, focusing on peripheral actors enrolled in the Program execution. These two perspectives of investigation made possible to understand how the content of PNPB has been modified by peripheral actors during its execution, generating unexpected results and frustrating some of the central actor's expectations. The innovation policy characteristics of PNPB also made possible to study the Program as a coordinated effort aiming to create a sectoral innovation system (Malerba, 2002) centered in the biodiesel industry.

Besides this introduction, the paper has been structured in five sections. The second section discusses the logic and policy instruments applied in biofuels insertion policies, which includes a short description of the policies implemented in countries that are leading the world biodiesel production. The third section describes and analyzes the Brazilian Program, using the legal and policy documents of PNPB's conception and implementation (top-down analysis). The fourth section of the paper describes the features and actions of public and private actors, both central and peripheral, that are relevant to the execution of PNPB (bottom-up analysis), and highlights the incongruences of these actors' actions related to the goals established at the PNPB official documents. Finally, the last section presents the paper's conclusions.

\section{Biofuels support public policies: a critical review of their logic and more frequently used instruments}

Since the beginning of the 1990's, several countries have reactivated policies adopted after the second oil shock of 1979. Nowadays these policies aim not only to diversify energy options, but include the goals of dynamizing the agroindustry sector and reducing environmental impacts that result from 
energy consumption, lowering fossil fuels consumption and thus "decarbonizing" the energy matrix (Grübler and Nakicenovik, 1996).

Among available alternatives, biofuels are frequently the target of public policies, due to the biofuels potential for generating positive environmental and social impacts, political feasibility. Also, due to similarities with petroleum fuels, it is possible to use the already existent distribution and consumption infrastructure.

International policy experience shows that the diffusion of biofuels depends on government support to be competitive with the lower prices of petroleum fuels. In order to overcome such market barriers, government interventions are conceived according to a neoclassical conception of the State as an "omniscient entity", capable of maximizing social welfare, correcting market failures, generating technological learning and minimizing uncertainties (Rajagopal and Zilberman, 2007).

In Neoclassical theory, market failures addressed by biofuels public policies are necessary, first and foremost, to correct the non-internalization on the prices of energy of social and environmental costs generated by the production and consumption of petroleum fuels. Secondly, neoclassical conception considers biofuels policies a mechanism to counterbalance the monopoly power of petroleum fuels producers on energy markets, breaking the technological lock in that prevents the adoption of alternative fuels (Unruh, 2002).

Based on these arguments, neoclassical approaches for biofuels policies conception plainly justify government and consumers subsidies to the development of alternative fuels industries. Even the raise of fuels prices, according to this view, is considered the monetization of not accounted externalities generated by the prevailing energy systems. Moreover, biofuels policies are based on optimistic predictions that the costs of biofuels have a natural tendency to decrease as the result of virtuous cycles of learning, pushed by government actions to generate technological knowledge, such as the funding of research (technology push), and the creation of new protected markets (demand pull), based on measures such as the mandatory use of new fuels (Nemet, 2008). The combination of technology push and demand pull policy tools is considered a powerful induction mechanism to learning on sectoral innovation systems (Malerba, 2002) centered on biofuels technologies. The components of these systems are supposed to perform specific functions on the development of these industries induced by public policies (Hekkert et al., 2007; Bergek et al., 2008). These functions include generation and diffusion of knowledge, influence on technological change direction, promotion of industrial investment, creation of new markets, mobilization of human and financial resources, and legitimating new technologies by positive externalities generation (Bergek et al., 2008).

In most of the cases, biofuels diffusion policies combine two kinds of interventions: I. Direct interventions: tax incentives, mandatory use of biofuel blends, funding for industrial and research investments, regulatory framework; 2 . Indirect interventions: incentives for specific agroindustries, financial funding to adapted equipments purchases (Rajagopal and Zilberman, 2007).

With no claim to completion, three objections can be made to the idea that State is as an entity capable of correcting energy markets failures by building innovation systems: I. The idea that any organization could perfectly correct market failures is an unrealistic one, since these failures are inherent to market economies (Silva, 2009); 2. The assumption that the State has perfect knowledge of all variables necessary for policy success, including the prediction of results, does not considers that all public policies generate unexpected results (Pressman and Wildavsky, 1984); 3. The State is not neutral in its intervention policies, since the content of these policies depends on negotiation between interest groups that aim to maximize private benefits from the policy, generating government failures such as the State capture by private interests, clientelism and nepotism (Castro, 2002).

By pointing out government failures and the unpredictability of public policies results, the intention here is not to recommend a free market/liberalization policy approach based on "laissez faire, laissez aller, laissez passer" orientations on energy markets, where government intervention is essential. The recommendation proposed here is that the top-down implementation of biofuels policy could be improved by a bottom-up approach, which means a construction of a new conception that could include the participation of a variety of actors relevant to the biofuel industry development.

Despite government failures pointed in this article, public policies are behind the huge increase of world biodiesel production, from II million liters in 199I to one billion liters in 200I (Azevedo, 2010). This growth on production has become steady since 2003, when more aggressive biofuels diffusion policies were implemented in the European Community countries (EC) and in the United States. In 2008, the top five biodiesel producers of the world were Germany ( $25.4 \%$ of the biodiesel world output), United States (20.96\%), France (16.35\%), Brazil (9.46\%) and Argentina (8.65\%) (Azevedo, 20I0). Chart I shortly presents the main policies adopted in these countries referring to biodiesel diffusion (not including Brazil).

Recently, some of these biodiesel policies have been limited by restrictive measures. In EC, concerns related to the envi- 
ronmental impacts of biofuels production led to the creation of the 28/2009 Directive which recommends the adoption of criteria to certify that subsidized biofuels are economically, environmentally and socially sound. In addition, the Directive determines greenhouse emissions to be reduced in $50 \%$ by 2017. In Germany, the 2007 Energy Tax Act determines a progressive increase of taxation on biofuels (EurObserv'ER, 2009). The results of the Energy Tax Act were an increase on the idle capacity on German biodiesel production $(85 \%$ in 2008 ), the reduction of production or bankruptcy of $70 \%$ of German biodiesel producers and the pashing out of biodiesel sales in 14\% of the fuels stations in the country (Mabee et al., 2009). In the United States, phasing out of the Blender Tax Credit motivated the National Biodiesel Board (NBB) to call the United States Senate to extend the subsides, in order to prevent the biodiesel industry bankruptcy.

The aforementioned impacts of restrictive measures clearly shows how biofuels industry is dependent on government subsidies. This dependence puts into question the forecasts perception of sustainability from the biodiesel industry by learning processes and costs reductions. This conception questions are the same in the Brazilian Program's conception documents, discussed in the next section.

\section{Top-down analysis of PNPB}

Programs for biodiesel diffusion in Brazil were settled in the 1980s, motivated by the oil shocks in the 1970s (Azevedo, 2010). Nevertheless, these initiatives had little impact on establishing a biodiesel industry, and were phased out. It was not until the 2000s that biodiesel came back to the public policy agenda, influenced mainly by policies implemented in developed countries. In 2002, the Brazilian Program for Technological Development of Biodiesel (Probiodiesel) was launched by the Ministry of Science and Technology (MCT). In 2003, the "Program Green Fuel: Biodiesel" was launched by the Ministry of Mines and Energy (Gazeta Mercantil, 2002a).

The main difference between PNPB and these two programs is PNPB's inter-ministry structure. The Program has been conceived by the Presidential Office and put into operation by the Civil House of the Presidency, a President's advisory office. In 2003, an inter-ministerial working group coordinated by the Civil House was created by a Presidential Decree, in charge of evaluating the viability of biodiesel use and of providing a forum for debates with members

\begin{tabular}{|c|c|}
\hline Country & Policies adopted \\
\hline $\begin{array}{l}\text { European } \\
\text { Community }\end{array}$ & $\begin{array}{l}\text { Common Agricultural Policy (1992) allowed bioenergy crops to be grown on set aside lands. The EC } 30 \text { Directive } \\
\text { (2003) created goals for the partial replacement of petrol fuels used for transport purposes by biofuels ( } 2 \% \text { until } \\
2006,5.75 \% \text { until } 20 \text { I I). The EC } 96 \text { Directive (2003) authorized EC member countries to give tax incentives to } \\
\text { biofuels producers. The Energy Crop Scheme (2003) authorized the payment of } 45 \text { euros by hectare of energy } \\
\text { crops grown on set aside lands. Research and development programs include the Altener Program (2005); the Sixth } \\
\text { Framework Program projects (I } 7.5 \text { billion euros applied in biofuels projects between } 2002 \text { and } 2006 \text { ), the Seventh } \\
\text { Framework Program projects ( } 53.2 \text { billion Euros between } 2007 \text { and } 2013 \text { ). In } 2003 \text {, diesel fuels specification on the } \\
\text { EC changed to include } 5 \% \text { of biodiesel. Also in 2003, a } 6.5 \% \text { tax is charged on imported biodiesel, and the EC specifi- } \\
\text { cations of biodiesel (EN I42 I4) have been created. }\end{array}$ \\
\hline Germany & $\begin{array}{l}\text { Tax exemptions for biodiesel were established in 1993. In } 1994 \text { biodiesel specifications were determined (DINV } \\
51606 \text { standards), updated in 1997. In 1999, increased petroleum fuels taxes were established, exempting biodiesel } \\
\text { (1999) and 5\% biodiesel blends (2004). The Biofuel Quota Act (2007) made mandatory the blend of a } 4.4 \% \text { of bio- } \\
\text { diesel on petroleum diesel that should increase to } 6.25 \% \text { in } 2009 \text { and } 8 \% \text { in } 2015 \text {. }\end{array}$ \\
\hline France & $\begin{array}{l}\text { In } 1992 \text {, increased petroleum fuels taxes were established, exempting biodiesel. In } 2000 \text {, a fixed amount of biodiesel } \\
\text { was permitted to commercialization free of taxes. The General tax on pollution-generating activities (2005) for fuels } \\
\text { resellers gave tax exemptions of } 33 \text { euros for each } 100 \text { liters of biodiesel added to petroleum diesel in } 5 \% \text { blends, } \\
\text { predicting a reduction on this discount to } 8 \text { euros in } 2011 \text {. }\end{array}$ \\
\hline United States & $\begin{array}{l}\text { Clean Air Act and Comprehensive Energy Policy Act (1992) promoted government vehicles fleet conversion to } \\
\text { alternative fuels, including biodiesel. In I } 994 \text { the National Biodiesel Board was created. In I } 997 \text { tax incentives for } \\
\text { converted vehicles were settled by the Clean Air Act. The American Society for Testing and Materials established } \\
\text { biodiesel specifications in } 200 \text { I. The Blender Tax Credit (2004) gave tax exemptions to producers and distributors } \\
\text { (US\$ I per gallon of biodiesel made from agricultural oils, and US\$ } 0.50 \text { per gallon of biodiesel made from waste oils } \\
\text { or animal fats). The Renewable Diesel Tax Credit (2005) created additional tax incentives to producers and distribu- } \\
\text { tors of biodiesel blends. }\end{array}$ \\
\hline Argentina & $\begin{array}{l}\text { The Competitiveness Plan for Biodiesel Fuels ( } 200 \mathrm{I}) \text { established tax incentives and government purchases of bio- } \\
\text { diesel for a } 15 \text { years period. In } 2007 \text {, the Biofuels Law made mandatory the blend of } 5 \% \text { of biodiesel on all petroleum } \\
\text { diesel commercialized in the country by } 201 \mathrm{I} \text {. }\end{array}$ \\
\hline
\end{tabular}

Chart I. Policies for biodiesel diffusion on European Comunity and he top four world biodiesel producers (not including Brazil). Source:Adapted from Azevedo (2010)

ISSN: 07 I8-2724. (http://www.jotmi.org)

Journal of Technology Management \& Innovation (c) Universidad Alberto Hurtado, Facultad de Economía y Negocios. 
of congress and representatives of the biodiesel network (research, agriculture, fuel and engine manufacturers, etc.). The viability study was elaborated by the working group and members of the Brazilian Agricultural Research Corporation (Embrapa), National Institute of Technology (INT), National Agency of Petroleum, Natural Gas and Biofuels (ANP), Brazilian Association of Vegetable Oil Industries (Abiove), Brazilian Automotive Engineering Association (AEA), Brazilian Association of Automotive Vehicle Manufacturers (Anfavea), farmers associations, congressmen and researchers (Grupo de Trabalho Interministerial, 2003).

In December 2003, the report produced by the working group was sent to the Civil House, and recommended the development of a biodiesel program based on international policy experiences, on the existence of Brazilian public and private institutions capable to lead biodiesel industry, and on environmental (decrease on vehicles emissions), economic (reduction of petroleum diesel imports) and social benefits (jobs creation in the poorest regions of Brazil).

The economic reasoning in favor of Brazil's biodiesel Program can be questioned if taking into consideration the growing production of petroleum diesel in Brazilian refineries. Besides, the production of biodiesel requires to increase methanol imports, the main non-agricultural input used in the biodiesel production [according to Medrano (2007), methanol used corresponds to $8 \%$ of the volume of biodiesel output] with a very small production in Brazil, which is dependent on imports of this product (Azevedo, 2010). The environmental benefits reasons are questionable by the non-existence of any regulatory measure to control environmental impacts of the agricultural raw materials cultivation (Garcez, 2008). Furthermore, the alleged reduction on fuel burning emissions is not significant with the use of low concentration biodiesel blends, between $2 \%$ and $5 \%$, proposed by the Brazilian Program (Medrano, 2007).

Based on the highly questionable reasoning of the report, in 2003 a Civil House Decree has created an Inter-ministerial Executive Comission for Biodiesel (CEIB) that was in charge of elaborating, implementing, and monitoring a biodiesel insertion program (Grupo de Trabalho Interministerial, 2003). The CEIB was composed by members of the Social Communication Secretariat and 30 ministers. In addition, a management group was settled to implement the strategies proposed by the CEIB. The management group was coordinated by the Ministry of Mines and Energy and was composed by Brazil's National Bank for Economic and Social Development (BNDES), the National Agency of Petroleum, Natural Gas and Biofuels (ANP), Petrobras (Brazilian Petroleum Corporation) and the Brazilian Agricultural Research Corporation (Embrapa).
In September 2004, the Brazilian Presidency of the Republic launched Provisional Measure (MP) Nr. 214/04. MP Nr. 214/04 established that ANP should be responsible for regulating the production and use of biodiesel, generating deadlines for achieving a certain mixture of biodiesel in petrodiesel. In addition it was determined that the National Council of Energy Policy (CNPE) should monitor the market insertion of the product and instituted a tributary model and mechanisms for social certification. The MP was an issue intensely discussed on Brazil's Congress: 18 amendments were proposed to alter the MP, including the mandatory use of biodiesel blends, which was not included on the original proposal. In fact, the mandatory use of biodiesel blends was included in the Program as a result of lobbying activities by the Brazilian Association of Vegetable Oil Industries (Abiove). The newspapers debate between defenders and opponents related to the mandatory use of fuel blends in Brazil was analyzed by Azevedo (20I0)

The Provisional Measure has been consolidated by Law Nr. I I.097/2005. This Law changed previous laws [Laws Nr. 9.478/1997, Nr. 9.847/1999 and Nr. 10.636/2002] related to the liquid fuels industry, and made the addition of biodiesel to commercialized oil diesel mandatory in Brazil, beginning with a $2 \%$ proportion as of 2008 (B2 Diesel) and $5 \%$ (B5 Diesel) starting in 2013. Additionally, Law Nr. II.097/2005 authorizes the National Council of Energy Policy (CNPE) to change the mandatory deadlines according to factors related to raw materials supply, biodiesel processing capacity, participation of small farmers, reduction of regional inequalities, technical problems faced by final devices users, and adequacies to industrial policies.

The MP Nr. 227/2004 implemented tax incentives, defining that taxation of biodiesel could never be superior to taxation of petroleum diesel. The MP also determined differentiations in tax exemptions according to the type of raw oil used in production, size of supplier farmers and region where the oil crops are cultivated. The tax reductions could reach $100 \%$, in the case of castor oil and palm oil small producers on the North, Northeast and semi-arid regions of Brazil.

The Presidential Decree Nr. 5.297/2004 established the 'Social Fuel Seal', a certification label that assures tributary advantages and access to financial credit for biodiesel producers, besides being a requirement for producers wishing to participate in ANP public auctions of biodiesel. In order to be certified, companies must purchase a proportion of their raw material from farmers registered in Pronaf ( $\mathrm{Na}-$ tional Programme for Expansion of Family Agriculture) and provide them technical assistance.

The MP also determined that the biodiesel market should be controlled by ANP, responsible for authorizing the produc- 
tion of biodiesel in mixtures above $2 \%$ for self-consumption and for private fleets. ANP for also responsible for setting quality standards (specifications and methods for testing). The CNPE Resolution Nr. 3/2005 also settled that biodiesel produced to be blended with petrodiesel should only be sold by industrial facilities in public auctions promoted by ANP. The maximum amount of biodiesel traded, as well as the reference prices, are also determined by ANP.The reference prices are the maximum price that producers should charge for their products in public auctions; distributors (buyers) acquire the biodiesel with the lower prices charged. The public auctions aims to assure that the amount of biodiesel necessary for the mandatory blend is made by certified producers, making easier to ANP to control the market and the quality standards of the fuel (Pezzo, 2009). Between 2005 and 2010,ANP has promoted 18 public auctions, assuring the blend of biodiesel during this period, corresponding to more than 5 million cubic meters of biodiesel.

Despite the steady increase in biodiesel output production since the beginning of the Program, the execution of PNPB caused changes in the original conceived policy project, for example, reducing the incentives of small farmers participation in the supplying of alternative raw materials such as castor oil or palm oil [both castor oil and palm oil are crops typical from the poorest regions on Brazil, the North and Northeast regions]. The mandatory use of blends, not recommended on PNPB conception step, became one of the Program's key instruments, and was subject of changes several times due to lobbying activities by the biodiesel and vegetable oils industries (Brito, 2008; Tenório, 2009): CNPE Resolution Nr. 2/2008 determined that the amount of biodiesel in petroleum diesel should rise from $2 \%$ to $3 \%$ in 2008; CNPE Resolution Nr. 2/2009 increased the amount to $4 \%$ in 2009; CNPE Resolution Nr.6/2009 implemented the use of $5 \%$ blends in 2010. The mandatory use of biodiesel blends required to biodiesel industry to purchase a huge amount of vegetable oils and fats in a short period of time (four years), and this volume could only be provided by big farmers. As a result big farmers are the main suppliers of fats and vegetable oils for biodiesel production, thus impairing PNPB's goals of including small farmers in the Program.

In fact, the Social Fuel Seal rules were modified in a harmful way to achieve the social inclusion purposes of PNPB in four different times: I. In 2007, due to the low offer of oils and fats in the market, the Social Fuel Seal was no longer a requirement for producers' participation in ANP's public auctions. As a result, about $15 \%$ of biodiesel acquired in 18 public auctions between 2005 and 2010 has been supplied by producers without social certification; 2 . In 2008 the $100 \%$ tax exemptions, once restricted to castor oil and palm oil biodiesel, has been extended to any agricultural raw material produced by family farmers on the North, Northeast and semi-arid regions; 3 . In 2008, the taxation for biodiesel production with raw materials supplied by big farmers was reduced, making less attractive to contract raw materials supply from small farmers; 4 . In 2008, the Social Fuel Seal certification regional criterion for raw materials acquisition was also altered. The requirement for biodiesel producers to acquire $50 \%$ of agricultural oils from family farmers on the Northeast and semi-arid regions dropped to $30 \%$; on the other side, the requirements for North e Central-West regions have raised from $10 \%$ to $15 \%$. It is important to highlight that the Central-West region of Brazil is a consolidated agribusiness region, predominantly occupied by industrial farmers. The North of Brazil is an expansion region, also with a strong presence of big farmers. The average size of big farms in the Northeast region is 177 hectares; in the North region, 609 hectares; in the Central-West Region, 944 hectares (Azevedo, 20I0).

\section{Bottom-up analysis of PNPB}

\section{Public-Sector Groups in the Brazilian Biodiesel Industry}

The group of public actors with first importance for the implementation of PNPB are Federal Government Ministries. Even though 13 Ministries are formally participants in the Program, only six have performed actions directly related to PNPB. Information about Ministries measures has been gathered from government publicly available planning documents, specifically at the Plurianual Government Plans (PPAs) reports, Federal Government covenants and contracts, and the Transparency Portal of Federal Government (Azevedo, 20l0).

In the 2004-2007 and 2008-20II PPAs, twelve biodiesel related actions have been identified, with a forecasted investment of US\$380 million. According to information available in the PPAs reports, $35.7 \%$ (US\$ I 36 million) of all scheduled resources was spent on execution; $38.4 \%$ had to be shared among Ministry of Agriculture, Livestock and Food Supply (MAPA); 19\% were designated to the Ministry of Agrarian Development (MDA); 3.7\% to the Ministry of Science, Technology and Innovation (MCTI).The Ministry of Mines and Energy (MME) and the Ministry of National Integration (MI) did not spend any biodiesel budgetary resource, even though these Ministries had resources scheduled on PPA.

Federal Government expenses on Covenants for the biodiesel Program reached US\$16 million, spent in 41 covenants in the period 2004-2008. MCTI have spent $51.9 \%$ from the total amount in 16 covenants; MDA, also in 16 covenants, has spent $31.6 \%$ of the total; MME signed three covenants, summing up $9.4 \%$ of the resources spent; $\mathrm{Ml}$ also signed three covenants that absorbed $5.9 \%$ of total resources; and 
MAPA was responsible for $0.9 \%$ of the resources spent, in three covenants. The external institutions with the higher amount of covenant resources have been first universities and research institutes, followed by agricultural producers associations, Non Governmental Organizations (NGOs) dealing with social services, State Governments Secretariats of Science and Technology and Municipalities.

Between 2004 and 2010, biodiesel related to Ministries contracts reached the amount of US\$ $\$ .5$ million. Most of these expenses $(82 \%)$ were directed invested in research projects and in acquisition of biodiesel equipment by Ministries operational bodies. The remaining amount (18\%) has been spent in operating expenditures, advertising, and events.

It is important to highlight the significant amount of federal financial resources spent by MCTI through its agencies: the Financing Agency for Studies and Projects (Finep) and the National Council for Scientific and Technological Development (CNPq) (Azevedo, 2010). Between 2002 and 2009, these two agencies invested in 368 biodiesel research projects, spending a total amount of US\$ 65 million (32\% spent by $\mathrm{CNPq}$ and $68 \%$ by Finep) (SIGCTI, 20I0). Before the implementation of PNPB (2002 to 2004 period), only seven biodiesel research projects have been funded by Finep and $\mathrm{CNPq}$, totalizing a total amount of US\$ 1.4 million. Biodiesel related projects were responsible by $1.95 \%$ of all the resources spent by Finep and CNPq between 2002 and 2009, most spent after PNPB's implementation (Azevedo, 20I0). Most of MCTI's resources were spent in projects developed by institutions located in the Northeast region, coherently with the priority given to this region on PNPB conception. Institutions of the Southwest and South regions were responsible for $74.83 \%$ of total resources. Projects supported by $\mathrm{CNPq}$ were carried out by universities $(86.95 \%)$ and research institutes (13.05\%). Projects funded by Finep had the participation of universities $(45.93 \%)$, research institutes (29.05\%), private companies (22.95\%), State Governments Secretariats of Science and Technology (I.II\%) and State Government Foundations for research support (0.96\%).

The budget analysis of Federal Government Ministries actions reveals a great emphasis placed on Science and Technology development with high participation of research institutes and universities as Ministries budget shows.

A second public actor essential to PNPB execution is Petrobras, the Brazilian publicly traded Petroleum Corporation controlled by Brazilian Federal Government. Petrobras business plans had scheduled investments in biodiesel since 2008. In the period of 2008 to 2012 , US $\$ 218$ million were scheduled in biodiesel (corresponding to $0.39 \%$ of the total investment scheduled by Petrobras); in the 2009-20I3 period, the scheduled investments reached US\$
225 million $(0.25 \%$ of the total investment scheduled). Between 2010 and 2014 , US $\$ 200$ million $(0.18 \%$ of the total investment scheduled by Petrobras) were planned for biodiesel investments.

In 2006 Petrobras began the construction of three biodiesel facilities in the Northeast and semi-arid regions (States of Bahia, Ceará and north region of Minas Gerais). The investment in these three units reached US\$ I I 5 million (Queiroz, 2007). The facilities were built by Intecnial, a Brazilian industrial construction company that uses technology licensed by the United States Company Crown Iron Works (Petrobras, 2010). Two facilities begun operations in 2008 and in 2009. By the end of 2009 , Petrobras acquired $50 \%$ of the private biodiesel factory Bsbios (located in the Paraná State, on South Brazil), with an investment of US\$28 million. In 2006 Petrobras invested US\$10 million in two experimental biodiesel facilities in Rio Grande do Norte State, located in the Northeast region of Brazil (Queiroz, 2007). The investments of Petrobras in biodiesel facilities located on Northeast Brazil (the poorest region on Brazil) pointed that the company is one of the Government instruments used in order to achieve social inclusion aims of PNPB.

In 2008 a subsidiary company, Petrobras Biofuels, was launched to manage biodiesel and ethanol projects of Petrobras. Petrobras Distributor, a subsidiary for fuels distribution, has invested US\$ 18 million in logistics and adaptation for fuel distribution (Martins, 2007). Petrobras also invests in Research and Development in a project named Technology Program on Renewable Energy (Proger), established in 2004. Petrobras is the top Brazilian institution in biodiesel patents registration: between 2003 and 2010, 12 biodiesel Petrobras's patents (out of 20 Brazilian patents) have been registered in patents offices in foreign countries; II patents have been registered during the same period in the Brazilian patents office, from a total of 192 patents deposits (32 from foreign institutions and 160 from Brazilian institutions) (Azevedo, 20I0).

Notwithstanding the huge investment of Petrobras in industrial biodiesel activities, the more important function of Petrobras in the PNPB is the acquisition of biodiesel at the public auctions promoted by ANP. On the 18 public auctions promoted by ANP, Petrobras and its subsidiary Refap (Alberto Pasqualini Refinery) were the only companies that bought biodiesel, at higher prices than those of petroleum diesel. The public auctions rules determine that only producers and importers of diesel that have more than $1 \%$ of participation on the diesel market are obliged to acquire biodiesel, what in effect makes Petrobras e a Refap the only companies obliged to buy biodiesel in ANP's public auctions. The biodiesel bought by the company is subsequently transferred to fuels distributors for blending with petroleum diesel. 
On the other hand, Petrobras activities in the biodiesel industry could be considered a strategic investment, necessary to the absorption of knowledge related to new energy sources. In fact, nowadays this is a very common strategy of petroleum companies that are investing in biofuels as a diversification strategy (Eikland, 2006).

State governments are the third relevant group of public actors in PNPB. The creation of State Programs was one of the action guidelines of PNPB made in order to decentralize biodiesel decisions and to create regional networks of public and private institutions in accordance with PNPB's goals. The perceived benefits for State Governments participation on the PNPB includes opportunities to receive federal funds to finance industrial, agricultural, energy, social and environmental State policies through local biodiesel programs. In 2004 an agreement between the ministries of MCTI, MME and State Foundations for Research Support allowed transference of Federal Funds (from the Sectoral Funds and from the Program for Amazon Investments) to State programs. Twenty one States received Federal funds, for State Secretariats, Foundations and Research Institutes (Azevedo, 2010).

Nevertheless, it is not fair to say that the covenants and Federal resources transfers led to the creation of a stable, enduring and institutionalized State biodiesel programs. A considerable share of Federal resources was directed to short-lived projects ( 24 months) executed by research institutes and universities, based on the erroneous conception that the overcoming of specific technological problems would be sufficient to turn biodiesel State programs viable. This erroneous conception of self-sufficient technological development is noticeable on Federal Government actions, which consider that the funding of R\&D measures could automatically generate innovations transferable to sectors of society. This is quite evident in projects funded by Finep with the objective of structuring State programs. Most of these projects are merely research projects focused on very specific problems, with the absence of market and institutional concerns, essential for the creation of long lasting and impactful policies. For instance, the projects for biodiesel pilotunits construction in Northeast region (Pernambuco, Rio Grande do Norte and Ceará States) has not been enough to assure the construction of any private biodiesel factory to be supplied by local oil crops farmers. Neither university projects on the poorest regions were able to change the tendency of the Brazilian biodiesel industry to be located in regions where the commodities agro-industry is stronger (as shown in the next section of the paper).

The analysis of public institutions actions on the PNPB makes clear that these are not sufficient to achieve PNPB's goals. Even though the biodiesel production capacity for manda- tory blends has been successfully achieved, the growth of biodiesel industry did not promote the regional development and the social inclusion aims proposed on the conception and formulation of PNPB. The mismatch between expected objectives and results achieved by the Program will be described in the next section, which addresses actions of private actors in the Brazilian biodiesel industry.

\section{Private-Sector Groups in the Brazilian Biodiesel Industry}

The first private-sector actors group in order of importance for PNPB is the agroindustrial complex related to oil and fats production and processing. The group is composed by small farmers, big farmers and fats and vegetable oils industry.

Despite government's incentives for the production of alternative oil crops (castor oil and palm oil), between 2008 and $2010,79.03 \%$ of the Brazilian biodiesel production was made from soybeans oil; $15.17 \%$, from beef tallow, and 3.33\% from cotton oil. Other oils had less than $1 \%$ participation on biodiesel production during this period. Thus, it is very clear that the oils and fats used in Brazilian biodiesel production are by-products of export oriented commodities (soybeans, beef and cotton), produced by big farmers or by small farmers already integrated into organized agroindustrial commercial chains (Azevedo, 20I0).

The proportion of biodiesel produced from family farmers' raw materials in the public auctions promoted by ANP shows the small participation of small farmers excluded in the commercial markets. In the II States enrolled in the Program, where family producers supplied agricultural oils to biodiesel production in 2008, only in the Rio Grande do Sul State (a region where family farmers are commonly integrated into agro-industrial commercial chains) there was a satisfactory participation of family farmers in the process of supplying oil to biodiesel facilities, reaching $61.39 \%$ of the State's production of raw material designated to the biodiesel facilities. In Goiás State (a region of agroindustry in central-west Brazil) family farmers participation reached $24.65 \%$, and in Mato Grosso State (also an agro-industry zone in the central-west region) family farmers supplied $9.84 \%$ of the raw material used on the State biodiesel facilities in 2008. In the Santa Catarina State (south Brazil region) the family farmers supply reached $2.27 \%$, and in Pará State (North region), I. 16\%. On the remaining States [Minas Gerais, Bahia, Ceará, Piauí, Rio Grande do Norte and Pernambuco], family farmers participation did not reach $1 \%$ in the production of raw materials used by biodiesel facilities (Leite, 2009). It is noticeable that the States where family farmers' participation was greater were those located in regions that lead soybeans production in Brazil: the central- 
west region produced $48.1 \%$ of the Brazilian soybeans output in 2008 , and the south region $34.48 \%$. Also, these two regions concentrate $77.5 \%$ of Brazilian soybeans processing capacity (Azevedo, 20I0). Not by chance, in $200895.94 \%$ of the agricultural oils supplied by family producers for biodiesel production in 2008 were soybean oil (Leite, 2009).

The significant participation of agricultural commodities on biodiesel raw materials commercialization can be explained by their highly organized markets and to the steady technical improvements on agricultural techniques for these crops. The situation for alternative crops is not the same, as shown by production and productivity data (Chart 2):

There is no official data related to the participation of family farmers on palm oil production. Nevertheless, data gathered from the biggest national producers in the States of Pará and Bahia allows the conclusion that this is a crop dominated by big farmers. In Pará State, the Agropalma Group had in 2010 32,000 hectares of palm plantations (Azevedo, 20I0), 64.5\% of the State's total of palm crops. In Bahia State, palm oil is processed by 4 companies that rule palm oil productive chain (Leiras, 2006). Castor oil problems include the low absorptive capacity for technical improvements and difficulties for obtaining funding and insurance (Garcia, 2006). This situation creates a vicious circle: producers are not able to absorb technical improvements due to their lack of financial resources, which they cannot obtain due to their technological gaps. This vicious circle has not been broken by the incentives to castor oil crops promoted by Brazil's Federal Government (Azevedo, 20I0).

The predominant utilization of agricultural commodities by-products for biodiesel production can be explained by the additional advantage of reducing costs and risks of commercial crops, by adding a new market to by-products. Thus, the soybeans crops, aimed at producing soybeans meals, have on the biodiesel market an option for commercializing the by-product soybean oil. The same occurs for beef producers (that sells beef tallow for biodiesel facilities) and cotton oil (a by-product of cotton crops, directed to fibers production). This is one of the reasons why commodi- ties crops oils (soybeans and cotton) are the raw materials that produce the less costly biodiesel in Brazil, according to Barros et al (2006).

Big producers of commodities are more integrated to the vegetable oils processing industry, making easier to establish supply contracts with biodiesel facilities. The same occurs with the family farmers that supply raw materials to the biodiesel industry. As shown in the previous section of this paper, the South and Central-West regions farmers are the main suppliers for the biodiesel industry. Soybean oil is the most used oil due to the low agronomic risks of soybeans crops and to the reduced needs of technical assistance for farmers. Finally, the dynamics of agro-industrial chains of commerce is reproduced in the biodiesel industry, because many of the biodiesel production facilities are owned by traditional agro-industry sector companies.

The second group of private-sector actors in importance for PNPB is the biodiesel production companies, in fact a new industry shaped after the launching of PNPB. Since 2005, but especially between 2007 and 2008, an investment boom in new biodiesel facilities occurred. In 2007, the production of facilities authorized by the ANP increased in $578 \%$ over 2006. Out of 36 companies that announced investments, 23 did so between 2007 and 2008. This huge increased investment in biodiesel facilities was caused by expectations of biodiesel use (B2) that become mandatory in 2008. The number of biodiesel facilities increased from eight facilities in 2005 to 64 in 2010, with a production installed capacity that increased from 85 thousand $\mathrm{m} 3$ per year to more than 5 million m3 per year. Nowadays, the biodiesel industry is a highly organized one, counting with institutions that are very active in the defense of the sector's interests. The more important of these institutions are the Brazilian Association of the Biodiesel Industries (Abiodiesel), founded in 2005, and the Brazilian Biodiesel Union (Ubrabio), established in 2007. ANP classifies Brazilian biodiesel facilities by their size, ranging from small (production capacity limited to $35,560 \mathrm{~m} 3$ of biodiesel per year), medium sized (limited to 126,000 $\mathrm{m} 3$ per year) and large size (biodiesel production superior to $126,000 \mathrm{~m} 3$ per year). 17 large facilities hold $68.76 \%$ of

\begin{tabular}{|l|l|l|}
\hline Crop & Production & Productivity \\
\hline Soybeans & $+22.3 \%$ & $+16.7 \%$ \\
\hline Cattle slaughtering & $+8.1 \%$ & $+19.8 \%$ \\
\hline Cotton & $+4.96 \%$ & $+14.1 \%$ \\
\hline Palm Oil Plant & $+20 \%$ & $+1.84 \%$ \\
\hline Castor Oil Plant & $-12 \%$ & $-3.6 \%$ \\
\hline
\end{tabular}

Chart 2. Biodiesel crops, production and productivity growth rates, Brazil, 2004-2008 Source:Azevedo (2010)

ISSN: 07 I8-2724. (http://www.jotmi.org)

Journal of Technology Management \& Innovation (c) Universidad Alberto Hurtado, Facultad de Economía y Negocios. 
Brazil's total biodiesel production capacity. Medium sized facilities hold $24.32 \%$ of Brazilian biodiesel production capacity in 17 facilities. Small sized facilities hold $6.92 \%$ of the total productive capacity in 30 facilities. All this 64 facilities have been authorized for operation by ANP, but only 29 facilities ( I 3 large facilities, I 3 medium-sized and three small) are certified by the Social Fuel Stamp, holding $75.74 \%$ of the Brazil's total biodiesel production capacity (Azevedo, 2010). Regional distribution of Brazilian biodiesel facilities in 2010, as well as Brazilian regions's participation on Brazil's biodiesel output between 2005 and 2010 are described in Chart 3.

As Chart 2 shows, few biodiesel facilities have been installed in the poorest regions of Brazil (North and Northeast), and most of the installed facilities belong to Petrobras. As stated before in this paper, Petrobras is one of the Federal Government instruments used to achieve the social aims of the Program. Besides, Petrobras is an integrated petroleum company, making possible to the company to absorb losses in its biodiesel business, compensated by petroleum production revenues. On the other side, companies dedicated exclusively to biodiesel production installed in the Northeast region had serious business problems, and maintained their operations by the acquisition of agricultural raw materials supplied by agro-business emergent producers from Northeast, such as the cotton and soybeans producers in Bahia State (Azevedo, 20I0).

The companies that own biodiesel facilities can be divided into three core businesses: agro-industry, independent production and biodiesel facilities supply (Azevedo, 20 I0). 26 facilities, that hold $59.3 \%$ of Brazil's total biodiesel production capacity, are agroindustrial companies (oil seeds processors, beef processors and large farmers cooperatives). 28 facilities (39.19\% of Brazil's total biodiesel production capacity) are independent ones, established exclusively for biodiesel production. Three small facilities can be classified as equipment suppliers, focusing on biodiesel facilities sales, and using their own facilities as demonstration units. Finally, the small facility Nutec (Ceará Industrial Technology Foundation) belongs to Ceará State Government, and it is in fact an experimental small facility, with production capacity of $864 \mathrm{~m} 3$ of biodiesel per year.
The number of facilities related to agroindustry companies helps to explain the prominence of agro-industry productive chains on the Brazilian biodiesel business, especially soybeans and beef tallow produced in the Central-West and South regions. The facilities owned by agro-industry companies use their own raw materials, or buy it from already integrated producers. This evidence reinforces the thesis that one of the main difficulties for PNPB's social inclusion objectives comes from the dynamics of biodiesel raw materials market, which reproduces agro-industry markets dynamics.

Regarding the industrial processes adopted by Brazilian biodiesel facilities, it is worth to investigate in detail the transesterification technologies adopted by Brazilian facilities. Oils and fats transesterification processes are the more widely used technologies for biodiesel production. The most common transesterification routes are methanol transesterification (using $8 \%$ of methanol of total biodiesel output on the process) and ethanol transesterification (using $12 \%$ of ethanol) (Azevedo, 2010). On both routes, the alcohol used becomes a component of the biodiesel produced. Most of Brazilian biodiesel production capacity $(78.97 \%)$ is based on methanol transesterification; $\mathbf{1 7 . 7 4 \%}$ of the capacity belongs to mixed facilities (facilities that can use either methanol or ethanol); only $3.29 \%$ of Brazil's biodiesel production capacity is installed on ethanol transesterification facilities (Azevedo, 20I0). Since $8 \%$ of the final biodiesel produced is composed by the alcohol used on the transesterification process, the predominance of the methanol route on Brazilian facilities brings up at least two disadvantages. Firstly, methanol in Brazil is produced mainly from natural gas, a fossil fuel, endangering the renewable character of Brazilian biodiesel (in fact, it can be said that almost $8 \%$ of all biodiesel produced in Brazil is a fossil fuel). Secondly, Brazil is a net importer of methanol, reducing the economic advantages of biodiesel production as a strategy to reduce expenses on petroleum diesel imports. In fact, Brazil's methanol imports have grown $4.72 \%$ between 2006 and 2007, 13.55\% between 2007 and 2008, 21.55\% between 2008 and 2009 and $27.57 \%$ between 2009 and 2010 . These numbers provide strong evidence that the mandatory use of $2 \%$ biodiesel blends since 2008 provoked an increase in methanol imports by Brazil (Azevedo, 20l0).

\begin{tabular}{|l|l|l|l|}
\hline Region & Brazil's installed capacity in \% & Number of facilities & National biodiesel output in \% (2005-20I0) \\
\hline Central-West & $41.38 \%$ & 29 & $40.49 \%$ \\
\hline South & $25.08 \%$ & 9 & $25.52 \%$ \\
\hline Sotheast & $17.34 \%$ & 15 & $16.76 \%$ \\
\hline Northeast & $11.76 \%$ & 7 & $14.17 \%$ \\
\hline North & $3.07 \%$ & 6 & $3.08 \%$ \\
\hline
\end{tabular}

Chart 3. Regional distribution of biodiesel facilities and biodiesel production, Brazil, 2005-20I0 Source:Azevedo (2010)

ISSN: 07I 8-2724. (http://www.jotmi.org)

Journal of Technology Management \& Innovation (c) Universidad Alberto Hurtado, Facultad de Economía y Negocios. 
Another problem is the utilization of imported technologies in the majority of Brazilian facilities. Even Petrobras' facilities were built with technology licensed from the United States Company Crown Iron Works. Other suppliers of technology to Brazilian facilities are the Italy Company DeSmet Ballestra, and the Germany Company Westfalia, associated to the United States Company Archer Daniel Midland (ADM). Those companies have supplied at least thirteen biodiesel facilities in Brazil, which hold $48.41 \%$ of the total biodiesel Brazilian production capacity. Due to difficulties on information related to the technology used by Brazilian biodiesel facilities, Azevedo (20I0) considers this estimative of imported technology participation underestimated, what means that certainly the imported technology participation on Brazilian biodiesel industry is higher.

The only big company that supplies biodiesel units in Brazil is the Company Dedini, traditional in the production of equipment for alcohol distilleries, and provider of biodiesel technology licensed by DeSmet Ballestra. Other Brazilian facilities suppliers are small companies, mainly start-ups created in universities and small processor of oilseeds and sugarcane that consider the biodiesel industry an opportunity to business diversification (Azevedo, 2010).

Besides making clear the Brazilian industrial gap in large biodiesel facilities technologies, the numbers shown above are evidences of unexpected results that arise from the mandatory use of biodiesel blends by PNPB. This unexpected effect was the need to import technology to produce biodiesel in large scale in a short period of time (four years), a requirement for providing the amount of biodiesel necessary to accomplish the mandatory blend targets. The short time necessary to achieve those targets made impossible for national industries to develop indigenous biodiesel production technologies.

\section{Conclusions}

The National Program for Production and Use of Biodiesel (PNPB) is a public policy aiming to create a sectoral system of innovation that could make feasible the insertion of biodiesel in the Brazilian energy matrix, in an environmentally correct way, promoting social inclusion with economical feasibility. In order to achieve these purposes, a set of rules and institutions has been created aiming to induce public and private actors to develop actions in synchrony with PNPB's objectives.

Nevertheless, the Program's implementation, making mandatory the use of blends in a short period of time (four years), associated with the changes in its social inclusion rules jeopardized the Program's more important target: the inclusion of small farmers of the poorest Brazilian regions.
The public-sector actors in charge of the policy execution (service deliverers) have proved not to be sufficient to assure PNPB's social inclusion objectives.

Ministries actions analyses have firstly shown that some Ministries that could be very relevant for PNPB's social and environmental targets (such as the Ministry of Environment and the Ministry of Labor and Employment) have only a formal participation in the Program. Besides, the Ministries that developed actions on the PNPB have worked with small budget resources. Scheduled actions have had a small proportion of financial execution, and were much focused on R\&D academic projects, whose results (if any) have not been transferred to the Brazilian biodiesel industry, especially to the actors located in the poorest Brazilian regions.

Petrobras, the Brazilian Petroleum Corporation, proved to be an essential actor for PNPB, especially in the acquisition of the biodiesel sold at the ANP's public auctions. Nevertheless, its participation in the biodiesel industry is limited to the creation of medium-sized facilities that use imported production technology, although in the poorest regions of Brazil.

Brazil's States policies reinforce the conclusions related to the public-sector actors actions on the PNPB. Several States have been funded by Finep to boost State programs, which were merely isolated research projects, insufficient to generate a local biodiesel industry on these States. It is quite clear that the success of the biodiesel industry in Brazil's States depends on the existence of the commodities agroindustry, the more important factor affecting investment decisions of private actors in the biodiesel industry.

The agricultural raw materials producers situation shows that PNPB did not accomplished the goals of social inclusion of family farmers in the poorest regions of Brazil. The main suppliers of raw materials for the Brazilian biodiesel industry are big soybeans producers on the more developed agro-industrial regions in the country, that grow crops in big farms. The family farmers that supply raw materials to biodiesel facilities are those family farmers already integrated into the export agro-industries (soybean producers of the Central-West and South regions of Brazil).The participation of family farmers that grow alternative raw materials in the poorest regions of Brazil is nearly non-existent. The investigation on Brazilian biodiesel facilities also pointed out to the lack of social inclusion on the PNPB. Most of the biodiesel production capacity and output is concentrated on facilities located on the Central-West and South regions. Moreover, a big proportion of biodiesel facilities are agro-business companies, what reinforces the tendency these companies have to contract suppliers already integrated to the agro-industry. Another problem of the Brazilian biodiesel facilities are the 
technological routes adopted. The methanol transesterification technology, used in the majority of Brazilian biodiesel plants, can be considered not adequate to the Brazilian conditions. Firstly, this technology requires the use of a fossil fuel, since methanol used in Brazil is made from natural gas. Secondly, methanol in Brazil must be imported, making more desirable the adoption of the ethanol transesterification route. Furthermore, the investigation on biodiesel facilities equipments suppliers hass shown a high participation of imported technologies, which explains the predominance of methanol transesterification technology. The use of imported technology was a result of the need for fast growing of Brazil's biodiesel production, required to accomplish the production targets that made feasible the mandatory blend of biodiesel in petroleum diesel.

The bottom-up analysis of the Program has shown much of PNPB's problems and unexpected results, caused by actor's power asymmetries and by changes introduced on the Program's conception instruments. Most of these changes were induced by lobbying activities of peripheral actors, powerful enough to influence central actor's decisions. Three central problems have been identified on the bottomup analysis: first, the predominance of public-sector actors actions on R\&D activities, considered a "magic bullet" that could solve all the biodiesel industry problems; secondly, the low participation of the poorest family farmers; thirdly, the creation of an industry inadequate to Brazilian conditions, dependent on imported technologies.

The analysis of conception, implementation and execution of PNPB in this paper has demonstrated that the Program's shortcomings are a combination of technical, economical, political and social factors. These shortcomings combined made impossible the execution of PNPB on the way conceived by the Program's coordinators. Generally speaking, public and private actor's power asymmetries and changes in technical and economic contextual factors (including the Program rules changes) are the main factors that make difficult to PNPB's coordinators the achievement of the objectives stated on the Program conception documents.

\section{References}

AZEVEDO, A.M.M. (2010). Análise top-down e bottom-up de um programa de inovação tecnológica na área de energia: o programa nacional de produção e uso de biodiesel (PNPB). Tese (Doutorado). Departamento de Política Científica e Tecnológica, Universidade Estadual de Campinas, Campinas.

BARROS, G.S.C. (2006). et al. Custos de produção de biodiesel no Brasil. Revista de Política Agrícola, n. 3, 36-50.

BERGEK, A. et al. (2008). Functions in innovation systems: a framework for analyzing energy system dynamics and identifying goals for system-building activities by entrepreneurs and policymakers. In: Foxon, T.J. et al. Innovation for a Low Carbon Economy. Edward Elgar, pp. 79-III.

BIODIESELBR.COM. (20I0).ANP define tamanho das usinas pequenas, médias e grandes. Portal biodieselbr.com. Web: http://www.biodieselbr.com/noticias/bio/anp-tamanho-usinas-pequenas-medias-grandes-2903 I0.htm. [30/06/20I0]

BRITO,A. (2008). Alta da soja prejudica entrega de biodiesel. Folha de S.Paulo.

CASTRO, A.B. (2002). A rica fauna da política industrial e a sua nova fronteira. Revista Brasileira de Inovação, v.I, n.2, 253-274.

EIKELAND, P.O. (2005) Biofuels - the new oil for the petroleum industry? The Fridtjof Nansen Institute, 39 p.

EUROBSERVER. (2009) Biofuels Barometer. Systèmes Solaires, n. 192, pp. 54-77, Web: http://www.eurobserv-er. org/quest.html. [12/03/2010]

FREITAS, S. (2006).TSE proíbe peça da Petrobras sobre biodiesel. Folha de S. Paulo.

GARCEZ, C.A.G. (2008). Uma análise da política pública do Programa Nacional de Produção e Uso de Biodiesel (PNPB). Dissertação (Mestrado em Política e Gestão Ambiental). Universidade de Brasília, Brasília.

GARCEZ, C. A. G.;Vianna, J. N. S. (2009). Brazilian Biodiesel Policy: Social and environmental considerations of sustainability. Energy, 34, 645-654

GARCIA, J.R. (2007) O Programa nacional de produção e uso de biodiesel e a agricultura familiar na região nordeste. Dissertação (Mestrado em Desenvolvimento Econômico). Instituto de Economia, Universidade Estadual de Campinas.

ISSN: 07 I8-2724. (http://www.jotmi.org) 
GAZETA Mercantil. (2002). Brasil pode adotar o biodiesel. Gazeta Mercantil, p. C7.

GRÜBLER, A.; Nakicenovik, N. (1996). Decarbonizing the global energy system. Technological Forecasting and Social Change, v.53, n.I, 97-II0.

GRUPO De Trabalho Interministerial. (2003). Relatório final do grupo de trabalho interministerial encarregado de apresentar estudos sobre a viabilidade de utilização de óleo vegetal - biodiesel como fonte alternativa de energia. Brasília, 15 p.

HEKKERT, M.P. et al. (2007). Functions of innovation systems: a new approach for analysing technological change. Technological Forecasting and Social Change, v.74, n.4, 4I 3-432.

HOGWOOD, B. and Gunn, L. (1984). Policy analysis for the real world. Oxford University Press, Oxford/England, 289 p.

LEIRAS,A. (2006).A Cadeia Produtiva do Biodiesel: uma avaliação econômica para o caso da Bahia. Dissertação (Mestrado). Programa de Pós-Graduação em Engenharia Industrial da Pontifícia Universidade Católica do Rio de Janeiro.

LEITE, M.A.V. (2009). Programa Nacional de Biodiesel- Selo Combustível Social. Simpósio Brasil-França de energia: novos atores, novas relações geopolíticas e o papel da agroenergia. Web: http://catedradogas.iee.usp.br/palestras_simposio_brasil-franca/biodiesel_franca-brasil.pdf [14/05/2009]

LULA DA SILVA, L.I. (2005). Programa de rádio Café com ○ Presidente. Rádio Nacional, 28/I I/2005 (Transcription). Web: http://www.info.planalto.gov.br/download/Cafe_Presidente/pr962.doc. [12/05/2010]

MABEE, W.E. et al. (2009). Update on implementation agendas 2009: A review of key biofuel producing countries. IEA Bioenergy Task 39 Report, International Energy Agency, 72 p.

MAGOSSI, E. (20I0). Petrobras Biocombustível tem prejuízo de $R \$ 92$ milhões, Agência Estado.

MALERBA, F. (2002). Sectoral Systems of Innovation and Production. Research Policy, v.3I, n.2, 247-264.

MARTINS, J.A.S. (2007). Logística de distribuição de biodiesel no Brasil. II Seminario Latinoamericano y del Caribe de Biocombustibles, San Salvador.

MEDINA, H. (2007). Distribuidor prevê alta no preço do diesel. Folha de S. Paulo
MEDRANO, M.F. (2007). Avaliação da sustentabilidade do biodiesel de soja no Brasil. Dissertação (Mestrado em Política e Gestão Ambiental). Universidade de Brasília, Brasília, 98 p.

NEMET, G. (2008). Demand-pull energy technology policies, diffusion and improvements in California wind power. In: Foxon, T.J. et al. Innovation for a Low Carbon Economy. Edward Elgar, 2008, pp. 47-78.

NOGUEIRA, L.A. H. (2003). Biodiesel no Brasil: as questões essenciais. O Estado de S. Paulo.

PETROBRAS (20I0). Biodiesel. Web: http://www2.petrobras.com.br/Petrobras/portugues/perfil/Perfil_biodisel.asp [04/07/2010]

PEZZO, C.R. (2009). O programa nacional de produção e uso de biodiesel: análise da implantação e possíveis resultados. Dissertação (Mestrado em Planejamento de Sistemas Energéticos). Faculdade de Engenharia Mecânica, Universidade Estadual de Campinas, Campinas.

PRESSMAN, J.L.; Wildavsky, A. (1984). Implementation: how great expectations in Washington are dashed in Oakland. University of California, Berkeley.

QUEIROZ, M.S.Q. (2007). Biocombustíveis e a economia brasileira. Conferência Nacional de Bioenergia, São Paulo.

RAJAGOPAL, D.; Zilberman, D. (2007). Review of environmental, economic and policy aspects of biofuels. Policy research working paper 434I, The World Bank Development Research Group.

SECRETARIA De Imprensa Da Presidência Da República. (n.d.) Discursos e Entrevistas.Web: http://www.info.planalto. gov.br/ [19/0I/20lo]

SILVA, C.G.R.S. (2009). Compras governamentais e aprendizagem tecnológica: uma análise da política de compras da Petrobras para seus empreendimentos offshore. Tese (Doutorado em Política Científica e Tecnológica). Universidade Estadual de Campinas, Campinas.

TENÓRIO, R. (2009). Governo aumenta mistura de biodiesel e anima indústria. Gazeta Mercantil.

UNRUH, G.C. (2002). Escaping carbon lock-in. Energy Policy, v.30, n.4, 317-325. 